\title{
Effect of Integrated Nutrient Management on Productivity of Summer Groundnut (Arachis hypogaea L.)
}

\author{
F.G. Vala, P.M. Vaghasia*, K.P. Zala and D.B. Buha \\ Main Oilseeds Research Station, Junagadh Agricultural University, Junagadh, Gujarat, India \\ *Corresponding author
}

\begin{tabular}{l} 
K e y w o r d s \\
Groundnut, \\
Inorganic fertilizers, \\
Organic manures, \\
Biofertilizers, \\
Growth, Yield. \\
Article Info \\
$\begin{array}{l}\text { Accepted: } \\
17 \text { September } 2017 \\
\text { Available Online: } \\
10 \text { October } 2017\end{array}$ \\
\hline
\end{tabular}

A B S T R A C T

A field experiment entitled "Integrated nutrient management in bold seeded summer groundnut (Arachis hypogaea L.)" was carried out at College of Agriculture, Junagadh Agricultural University, Junagadh during the summer season of 2016. The experiment comprising ten treatments of nutrient management viz., $\mathrm{T}_{1}$ (control), $\mathrm{T}_{2}$ [Biofertilizer (Rhizobium and PSM)], $\mathrm{T}_{3}$ (FYM $5 \mathrm{t} \mathrm{ha}^{-1}$ ), $\mathrm{T}_{4}$ [100\% RDF (25-50-50-20 kg N-P $\mathrm{O}_{5}-\mathrm{K}_{2} \mathrm{O}-\mathrm{S}$ $\left.\left.\mathrm{ha}^{-1}\right)\right], \mathrm{T}_{5}(50 \% \mathrm{RDF}+50 \% \mathrm{~N}$ through FYM $), \mathrm{T}_{6}(50 \% \mathrm{RDF}+50 \% \mathrm{~N}$ through FYM +Biofertilizer), $\mathrm{T}_{7}\left(75 \% \mathrm{RDF}+\right.$ Biofertilizer), $\mathrm{T}_{8}(75 \% \mathrm{RDF}+25 \% \mathrm{~N}$ through $\mathrm{FYM}), \mathrm{T}_{9}$ $\left(75 \% \mathrm{RDF}+25 \% \mathrm{~N}\right.$ through $\mathrm{FYM}+$ Biofertilizer) and $\mathrm{T}_{10}(75 \% \mathrm{RDF}+25 \% \mathrm{~N}$ through Vermicompost + Biofertilizer) were evaluated in randomized block design with three replications. The experimental soil was clayey in texture, low in $\mathrm{N}$, medium in available $\mathrm{P}$, $\mathrm{K}$ and S. Bunch groundnut variety 'GJG 31' was tested in the experiment. The experimental results revealed that significantly higher values of growth parameters viz., plant height, plant spread, number of branches plant ${ }^{-1}$, number of root nodules plant ${ }^{-1}$ and root length; yield attributes viz., number of mature pods, pod weight plant ${ }^{-1}$ and yield viz., pod yield $\left(2324 \mathrm{kgha}^{-1}\right)$ and haulm yield $\left(3080 \mathrm{kgha}^{-1}\right)$; quality parameters viz., shelling per cent, 100 kernel weight, oil content and protein content were recorded under the application of $75 \%$ RDF $+25 \% \mathrm{~N}$ through FYM + Biofertilizer. Significantly, being at par with application of 50\% RDF + 50\% N through FYM + Biofertilizer, 75\% RDF + 25\% N through Vermicompost + Biofertilizer, $100 \%$ RDF (25-50-50-20 kg N-P $\left.\mathrm{O}_{5}-\mathrm{K}_{2} \mathrm{O}-\mathrm{S} \mathrm{ha}{ }^{-1}\right)$ and $50 \% \mathrm{RDF}+50 \% \mathrm{~N}$ through FYM.

\section{Introduction}

Groundnut is one of the most popular and universal crop cultivated in more than 120 countries. In India, it is cultivated on area of $5.53 \mathrm{M}$ ha with production of $9.67 \mathrm{M}$ tones and productivity of $1750 \mathrm{~kg} \mathrm{ha}^{-1}$ during 20132014 (AICRPG, 2015). Based on rainfall pattern, soil factors, diseases and pest situations, groundnut growing area in India has been divided into five zones. Currently six states viz., Gujarat, Andhra Pradesh, Karnataka, Tamil Nadu, Maharashtra and
Rajasthan account for more than $90 \%$ of the total groundnut area and $89.3 \%$ of total groundnut production. Madhya Pradesh, Uttar Pradesh, Odisha and West Bengal are the other states having substantial area under this crop. Among the major groundnut growing states, Gujarat rank first in area (1.84 M ha) and production (4.92 $\mathrm{M}$ tones) with productivity of $2670 \mathrm{~kg} \mathrm{ha} \mathrm{ha}^{-1}$ (AICRPG, 2015).Integrated nutrient management plays an important role in boosting groundnut 
production. In other words this concept refers to the maintenance of soil fertility and supply of plant nutrients on desired levels for obtaining optimum or higher groundnut production through all possible sources as organic, inorganic, biotic etc. in an integrated manner. The incorporation of bulky organic manures such as farmyard manure, vermicompost etc. play an important role in plant nutrition especially for nitrogen. Among the various agronomic practices, nutrient management has an important role in maximizing the pod yield. Judicial use of fertilizer is necessary for increasing agricultural production and reduced environmental pollution because continuous use of chemical fertilizers has deleterious effects on soil which in turn cause decline in productivity. Furthermore it caused low nutrient recovery and increase in cost of production and environmental pollution (Sarkar et al., 1997). Use of balanced fertilizer is required for maximum yields and maintenance of soil fertility. A balanced fertilizer means not only the use of major and secondary nutrients, but also other essential micronutrients in correct proportions. Nutrients affected all most growth and yield attributing characters and yields through its doses as well as sources. Considering the facts and views highlighted above, the present study was undertaken to assess the effect of integrated nutrient management in bold seeded summer groundnut (Arachis hypogaea L.).

\section{Materials and Methods}

A field experiment entitled "Integrated nutrient management in bold seeded summer groundnut (Arachis hypogaea L.)'" was carried out at College of Agriculture, Junagadh Agricultural University, Junagadh during the summer season of 2016. The experiment comprising ten treatments of nutrient management viz., $\mathrm{T}_{1}$ (control), $\mathrm{T}_{2}$ [Biofertilizer (Rhizobium and PSM)], $\mathrm{T}_{3}$
(FYM $5 \mathrm{t} \mathrm{ha}^{-1}$ ), $\mathrm{T}_{4}$ [100\% RDF (25-50-50-20 $\left.\left.\mathrm{kg} \mathrm{N}-\mathrm{P}_{2} \mathrm{O} 5-\mathrm{K}_{2} \mathrm{O}-\mathrm{S} \mathrm{ha}^{-1}\right)\right], \mathrm{T}_{5}(50 \% \mathrm{RDF}+$ $50 \% \mathrm{~N}$ through FYM), $\mathrm{T}_{6}(50 \% \mathrm{RDF}+50 \%$ $\mathrm{N}$ through FYM +Biofertilizer), $\mathrm{T}_{7}(75 \% \mathrm{RDF}$ + Biofertilizer), $\mathrm{T}_{8}(75 \% \mathrm{RDF}+25 \% \mathrm{~N}$ through FYM), $\mathrm{T}_{9}(75 \% \mathrm{RDF}+25 \% \mathrm{~N}$ through $\mathrm{FYM}+$ Biofertilizer) and $\mathrm{T}_{10}(75 \%$ $\mathrm{RDF}+25 \% \mathrm{~N}$ through Vermicompost + Biofertilizer) were evaluated in randomized block design with three replications. The soil of the experimental plot was clayey in texture and slightly alkaline in reaction with $\mathrm{pH} 7.9$, EC $0.38 \mathrm{ds} \mathrm{m}^{-1}$ and organic carbon $0.62 \%$. The soil was low in available nitrogen $\left(241.00 \mathrm{~kg} \mathrm{ha} \mathrm{ha}^{-1}\right)$, medium in available phosphorus $\left(31.60 \mathrm{~kg} \mathrm{ha}^{-1}\right)$, potash $(215.36 \mathrm{~kg}$ $\mathrm{ha}^{-1}$ ) and sulphur (17.5 $\left.\mathrm{mg} \mathrm{kg}^{-1}\right)$.Groundnut cv. GJG 31 was sown at $30 \mathrm{~cm} \times 10 \mathrm{~cm}$ spacing with $125 \mathrm{~kg}$ seed ha ${ }^{-1}$ in first week of February. The recommended dose of fertilizers@25:50:50:20 kg NPKSha ${ }^{-1}$ was considered as $100 \%$ RDF. The crop was fertilized as per treatments at the time of sowing, while well decomposed FYM containing $0.5 \% \quad \mathrm{~N}, 0.2 \% \quad \mathrm{P}_{2} \mathrm{O}_{5}$, and $0.5 \%$ $\mathrm{K}_{2} \mathrm{O}$ and vermicompost containing $1.5 \% \mathrm{~N}$, $1.0 \% \mathrm{P}_{2} \mathrm{O}_{5}$ and $1.5 \% \mathrm{~K}_{2} \mathrm{O}$ were applied based on the nutrient equivalent basis of groundnut nutrient requirement at preparation of soil. Seed was inoculated with a culture of Rhizobium plus PSM as per treatment before sowing. Other cultural operations were done as per recommendation and crop requirements. Regularly biometric observations were recorded at specific time intervals by selecting randomly five plants in each treatment. Finally the crop was harvested and produce were dried, threshed, cleaned and weighed. The yield data was subjected to statistical analysis.

\section{Results and Discussion}

\section{Growth attributes}

Groundnut growth parameters viz., plant height at harvest, plant spread at harvest, 
number of branches at harvest, number of root nodules per plant at $60 \mathrm{DAS}$ and root length at 45 and 60 DAS were significantly influenced by different treatments (Table 1).

Application of $75 \% \mathrm{RDF}+25 \% \mathrm{~N}$ through $\mathrm{FYM}+$ Biofertilizer $\left(\mathrm{T}_{9}\right)$ recorded significantly taller plants at harvest, higher plant spread, higher number of root nodules per plant, higher root length 60 DAS compared to control $\left(\mathrm{T}_{1}\right)$, it was remained at par with the treatments $\mathrm{T}_{10}, \mathrm{~T}_{6}, \mathrm{~T}_{8}, \mathrm{~T}_{3}, \mathrm{~T}_{5}$ and $\mathrm{T}_{4}$. The improvement in growth parameters with application of $75 \% \mathrm{RDF}+25 \% \mathrm{~N}$ through FYM + Biofertilizer, treatments $\left(\mathrm{T}_{9}\right)$, $50 \% \mathrm{RDF}+50 \% \mathrm{~N}$ through $\mathrm{FYM}+$ Biofertilizer $\left(\mathrm{T}_{6}\right), 75 \% \mathrm{RDF}+25 \% \mathrm{~N}$ through vermicompost + Biofertilizer $\left(\mathrm{T}_{10}\right), 75 \% \mathrm{RDF}$ $+25 \% \mathrm{~N}$ through FYM $\left(\mathrm{T}_{8}\right), 50 \% \mathrm{RDF}+$ $50 \% \mathrm{~N}$ through FYM $\left(\mathrm{T}_{5}\right), 100 \%$ RDF $25-50-$ $50-20 \mathrm{~kg} \mathrm{~N}-\mathrm{P}_{2} \mathrm{O}_{5}-\mathrm{K}_{2} \mathrm{O}-\mathrm{S} \mathrm{ha}^{-1}\left(\mathrm{~T}_{4}\right)$ Beneficial effect of FYM in conjunction with recommended dose of fertilizers and biofertilizers may be due to the effect of organic matter in improving physical, chemical and biological environment of soil conductive to better plant growth (Deshmukh et al., 2005). The organic sources of nutrients improved crop growth during later stages. The favourable effect of vermicompost and FYM on growth might be attributed to presence of relatively readily available plant nutrients, growth enhancing substances and number of beneficial organisms like nitrogen fixing, phosphate solubilizing, cellulose decomposing and other beneficial microbes as well as antibiotics, vitamins and hormones etc. Thus, favourable influence of nutrients to produce larger cells with thinner cell wall and its contribution in cell division and cell elongation which improved vegetative growth and ultimately increased plant height, plant spread, number of branches per plant, root length and number and dry weight of root nodules per plant. The findings are close with findings of Patil et al., (2014), Rahevar et al., (2015) and Sengupta et al., (2016).

\section{Yield attributes}

Groundnut yield attributes such as number of mature pods per plant at harvest and pod weight per plant (Table 1) were improved by integrated nutrient management treatments of $75 \% \mathrm{RDF}+25 \% \mathrm{~N}$ through $\mathrm{FYM}+$ Biofertilizer $\left(\mathrm{T}_{9}\right)$ which was remained statistically equivalent to the treatments $\mathrm{T}_{10}$, $\mathrm{T}_{6}, \mathrm{~T}_{7}, \mathrm{~T}_{4}$ and $\mathrm{T}_{3}$ in respect of mature pods per plant at harvest and $\mathrm{T}_{6}, \mathrm{~T}_{8}, \mathrm{~T}_{10}, \mathrm{~T}_{5}$ and $\mathrm{T}_{4}$ in respect of pod weight per plant. Increased values in these yield attributes might have been on account of the overall improvement in vegetative growth and nodulation, which favourably influenced the flowering and fruiting and ultimately resulted into increased number of matured pods and pod weight per plant. These findings agreement with the results obtained by Chaudhary et al., (2015), Madhu Bala and Kedar Nath (2015) and Rahevar et al.,(2015).

\section{Quality parameters}

The data in (Table 2) revealed that oil content, protein content, 100 kernel weight and shelling per cent were significantly influence by different nutrient management treatments. 100 kernel weight and shelling per cent, oil and protein content were registered higher under the treatmentT $9(75 \% \mathrm{RDF}+25 \% \mathrm{~N}$ through FYM + Biofertilizer). However, it is statistically equivalent to treatments $\mathrm{T}_{6}, \mathrm{~T}_{10}$, $\mathrm{T}_{7}, \mathrm{~T}_{8}, \mathrm{~T}_{4}$ and $\mathrm{T}_{5}$ in respect of 100 kernel weight and shelling per cent, while $\mathrm{T}_{8}, \mathrm{~T}_{5}, \mathrm{~T}_{10}$ and $T_{7}$ in respect of oil content and $T_{10}, T_{8}, T_{4}$ and $\mathrm{T}_{6}$ in respect of protein content. The increased in kernel weight and shelling, this might be due to improvement in nutritional environment which might have favourably influenced carbohydrate metabolism which in turn increased the uptake of nutrients and ultimately resulted in increased kernel weight and shelling per cent (Kaliyarasan et al., 2002). 
Int.J.Curr.Microbiol.App.Sci (2017) 6(10): 1951-1957

Table.1 Effect of different treatments on growth and yield attributes of summer groundnut

\begin{tabular}{|c|c|c|c|c|c|c|c|c|}
\hline & Treatments & $\begin{array}{l}\text { Plant } \\
\text { height } \\
(\mathrm{cm}) \\
\end{array}$ & $\begin{array}{l}\text { Plant } \\
\text { spread } \\
(\mathrm{cm}) \\
\end{array}$ & $\begin{array}{l}\text { Number of } \\
\text { branches } \\
\text { at harvest }\end{array}$ & $\begin{array}{c}\text { Number of } \\
\text { root nodules } \\
\text { / plant }\end{array}$ & $\begin{array}{l}\text { Root } \\
\text { length } \\
(\mathrm{cm}) \\
\end{array}$ & $\begin{array}{c}\text { Mature } \\
\text { pods }\end{array}$ & $\begin{array}{c}\text { Pod } \\
\text { weight / } \\
\text { plant (g) }\end{array}$ \\
\hline $\mathrm{T}_{1}$ & Control & 16.17 & 16.90 & 4.67 & 69.55 & 10.33 & 10.60 & 7.53 \\
\hline $\mathrm{T}_{2}$ & Biofertilizer (Rhizobium and PSM) & 17.13 & 17.77 & 5.33 & 72.33 & 10.80 & 10.73 & 8.63 \\
\hline $\mathrm{T}_{3}$ & FYM $\left(5 \mathrm{t} \mathrm{ha}^{-1}\right)$ & 18.90 & 19.50 & 6.33 & 69.85 & 12.57 & 11.57 & 8.67 \\
\hline $\mathrm{T}_{4}$ & $100 \%$ RDF $\left(25-50-50-20 \mathrm{~kg} \mathrm{~N}-\mathrm{P}_{2} \mathrm{O}_{5}-\mathrm{K}_{2} \mathrm{O}-\mathrm{S} \mathrm{ha}^{-1}\right)$ & 19.50 & 19.47 & 6.67 & 72.47 & 11.33 & 11.97 & 9.93 \\
\hline $\mathrm{T}_{5}$ & $50 \% \mathrm{RDF}+50 \% \mathrm{~N}$ through FYM & 21.07 & 18.70 & 6.00 & 78.52 & 12.67 & 11.22 & 10.37 \\
\hline $\mathrm{T}_{6}$ & $50 \% \mathrm{RDF}+50 \% \mathrm{~N}$ through FYM + Biofertilizer & 21.47 & 18.67 & 7.33 & 80.77 & 12.47 & 12.30 & 10.87 \\
\hline $\mathrm{T}_{7}$ & $75 \%$ RDF + Biofertilizer & 18.17 & 20.23 & 7.00 & 72.41 & 13.17 & 12.14 & 9.60 \\
\hline $\mathrm{T}_{8}$ & $75 \%$ RDF $+25 \% \mathrm{~N}$ through FYM & 23.43 & 19.73 & 8.00 & 73.85 & 11.83 & 11.50 & 10.83 \\
\hline $\mathrm{T}_{9}$ & $75 \% \mathrm{RDF}+25 \% \mathrm{~N}$ through FYM + Biofertilizer & 24.53 & 22.00 & 8.33 & 81.16 & 13.43 & 13.04 & 11.00 \\
\hline \multirow[t]{4}{*}{$\mathrm{T}_{10}$} & $75 \% \mathrm{RDF}+25 \% \mathrm{~N}$ through vermicompost + Biofertilizer & 22.03 & 20.33 & 7.67 & 80.69 & 13.03 & 12.74 & 10.53 \\
\hline & S.Em. \pm & 1.35 & 0.90 & 0.49 & 2.85 & 0.66 & 0.51 & 0.37 \\
\hline & C.D. $(P=0.05)$ & 4.03 & 2.67 & 1.48 & 8.47 & 1.98 & 1.51 & 1.10 \\
\hline & C. V. \% & 11.63 & 8.08 & 12.81 & 6.58 & 9.50 & 7.50 & 6.59 \\
\hline
\end{tabular}


Int.J.Curr.Microbiol.App.Sci (2017) 6(10): 1951-1957

Table.2 Effect of different treatments on quality and yield of summer groundnut

\begin{tabular}{|c|c|c|c|c|c|c|c|}
\hline & Treatments & $\begin{array}{l}\text { Pod yield } \\
\left(\mathrm{kg} \mathrm{ha}^{-1}\right)\end{array}$ & $\begin{array}{l}\text { Haulm yield } \\
\left(\mathrm{kg} \mathrm{ha}^{-1}\right)\end{array}$ & $\begin{array}{l}100 \text { Kernel } \\
\text { weight }(\mathrm{g})\end{array}$ & $\begin{array}{c}\text { Shelling } \\
(\%)\end{array}$ & $\begin{array}{l}\text { Oil content } \\
(\%)\end{array}$ & $\begin{array}{c}\text { Protein } \\
\text { content }(\%)\end{array}$ \\
\hline $\mathrm{T}_{1}$ & Control & 1714 & 2368 & 36.43 & 61.33 & 47.66 & 20.83 \\
\hline $\mathrm{T}_{2}$ & Biofertilizer (Rhizobium and PSM) & 1811 & 2536 & 38.30 & 62.33 & 48.03 & 22.08 \\
\hline $\mathrm{T}_{3}$ & FYM $\left(5 \mathrm{tha}^{-1}\right)$ & 1991 & 2496 & 37.41 & 64.00 & 48.81 & 22.20 \\
\hline $\mathrm{T}_{4}$ & $100 \% \mathrm{RDF}\left(25-50-50-20 \mathrm{~kg} \mathrm{~N}-\mathrm{P}_{2} \mathrm{O}_{5}-\mathrm{K}_{2} \mathrm{O}-\mathrm{S} \mathrm{ha}^{-1}\right)$ & 2256 & 2481 & 42.43 & 68.33 & 49.65 & 23.57 \\
\hline $\mathrm{T}_{5}$ & $50 \% \mathrm{RDF}+50 \% \mathrm{~N}$ through FYM & 2201 & 2617 & 41.20 & 67.67 & 50.17 & 21.98 \\
\hline $\mathrm{T}_{6}$ & $50 \%$ RDF $+50 \% \mathrm{~N}$ through FYM + Biofertilizer & 2200 & 2882 & 44.00 & 69.00 & 49.05 & 23.41 \\
\hline $\mathrm{T}_{7}$ & $75 \%$ RDF + Biofertilizer & 2114 & 2506 & 43.09 & 65.67 & 49.87 & 23.87 \\
\hline $\mathrm{T}_{8}$ & $75 \% \mathrm{RDF}+25 \% \mathrm{~N}$ through FYM & 2278 & 2276 & 42.46 & 67.00 & 50.82 & 24.81 \\
\hline $\mathrm{T}_{9}$ & $75 \% \mathrm{RDF}+25 \% \mathrm{~N}$ through FYM + Biofertilizer & 2324 & 3080 & 45.14 & 70.00 & 52.09 & 25.54 \\
\hline \multirow[t]{4}{*}{$\mathrm{T}_{10}$} & $75 \% \mathrm{RDF}+25 \% \mathrm{~N}$ through vermicompost + Biofertilizer & 2274 & 2908 & 43.86 & 69.67 & 49.93 & 25.02 \\
\hline & S.Em. \pm & 116 & 157 & 1.38 & 1.89 & 0.80 & 0.93 \\
\hline & C.D. $(\mathrm{P}=0.05)$ & 344 & 469 & 4.12 & 5.62 & 2.37 & 2.78 \\
\hline & C. V. \% & 9.50 & 10.46 & 5.80 & 4.92 & 2.80 & 6.95 \\
\hline
\end{tabular}


The increased oil and protein content might be due to the role of nitrogen and sulphur are an integral part of protein and phosphorus is structural element of certain co-enzymes involved in biosynthesis of oil and storage organs, which are proteinaceous in nature. These findings are in close conformity with those reported by Ola et al., (2013) and Madhu Bala and Kedar Nath (2015).

\section{Yield}

A perusal of data (Table 2) revealed that different treatments of nutrient management exerted their significant effect on pod yield of bold seeded summer groundnut. Significantly the highest pod yield of $2324 \mathrm{~kg} \mathrm{ha}^{-1}$ and haulm yield of $3080 \mathrm{~kg} \mathrm{ha}^{-1}$ was recorded under treatment $\mathrm{T}_{9}(75 \% \mathrm{RDF}+25 \% \mathrm{~N}$ through FYM + Biofertilizer) which was found statistically equivalent to treatments $T_{8}$, $\mathrm{T}_{10}, \mathrm{~T}_{4}, \mathrm{~T}_{5}, \mathrm{~T}_{6}, \mathrm{~T}_{7}$ and $\mathrm{T}_{3}$. The magnitude of increase in pod yield under treatments $T_{9}, T_{8}$, $\mathrm{T}_{10}, \mathrm{~T}_{4}, \mathrm{~T}_{5}, \mathrm{~T}_{6}, \mathrm{~T}_{7}$ and $\mathrm{T}_{3}$ to the tune of 35.59 , $32.90,32.67,31.62,28.41,28.35,23.33$ and 16.16 per cent over $\mathrm{T}_{1}$ (control), respectively. While, haulm yield were found statistically at par with treatments of $T_{10}, T_{6}$ and $T_{5}$. The extent of increase in haulm yield over control $\left(\mathrm{T}_{1}\right)$ was $30.07,22.80,21.71$ and 10.52 per cent with treatments $T_{9}, T_{10}, T_{10}$ and $T_{5}$, respectively. Pod yield and haulm yield was increased may be attributed to the reason that integrated nutrient use (organic, inorganic and bio-fertilizers) played the very important role due to their synergistic effect and also improved the soil environment, which encouraged proliferous root system resulting in better absorption of water, nutrients from lower layers and better development of plant growth leading to higher photosynthetic activity and translocation of photosynthates to the sink which in turn resulted in better development of yield attributes and finally higher pod yield and haulm yield. The present findings are in close agreement with the results obtained by Zalate and Padmani (2010), Patil et al., (2014) and Rahevar et al., (2015).

Based on field experimentation, it can be concluded that, higher growth, yield attributes and yield from bold seeded summer groundnut can be secured by application of $75 \%$ RDF(18.75-37.50-37.50-15 kg N-P $\mathrm{O}_{5^{-}}$ $\mathrm{K}_{2} \mathrm{O}-\mathrm{S}$ ha $\left.^{-1}\right)+25 \% \mathrm{~N}$ through FYM $(1.25 \mathrm{t}$ $\mathrm{ha}^{-1}$ ) + Biofertilizer (Rhizobium and PSM @ $10 \mathrm{ml} \mathrm{kg}^{-1}$ seed) on calcareous clayey soil of South Saurashtra Agro-climatic Zone of Gujarat

\section{References}

Anonymous. 2015. Annual Report (kharif 2014) of All India Coordinated Research Project on Groundnut. ICARDirectorate of Groundnut Research, Junagadh.

Chaudhary, J. H., Sutaliya, Ramdev and Desai, L. J. 2015.Growth, yield, yield attributes and economics of summer groundnut (Arachis hypogaea L.) as influenced by integrated nutrient management. Journal of Applied and Natural Science, 7(1): 369-372.

Kalaiyarasan, C., Vaiyapuri, V. and Sri Rachandra Sekharan, M. V. 2002. Effect of sulphur sources and levels on the growth and yield of groundnut in red laterite soil, Annals Agricultural Research, New Series, 23(4): 618-621.

Madhu Bala and Kedar Nath. 2015. Maximization of groundnut (Arachis hypogaea L.) yield by nutrient management practices. Journal of Experimental Biology and Agricultural Sciences, 3(3):241-245.

Ola, B.L., Pareek, R.S., Yadav, A.C. and Shivranand O.P. 2013. Influence of integrated nutrient management on productivity and quality of groundnut in western Rajasthan. Annals Agricultural 
Research New Series, 34(2):156-159.

Patil, S. R., Kadam, S. R., Kalegore, N.K. and Dadgale, P. R. 2014.Effect of inorganic and bio-fertilizers on growth and yield of summer groundnut. Advance Research Journal of Crop Improvement, 5(1): 23-25.

Rahevar, H.D., Patel, P.P., Patel, B.T., Joshi, S.K. and Vaghela, S.J. 2015. Effect of FYM, iron and zinc on growth and yield of summer groundnut (Arachis hypogaea L.) under North Gujarat Agro-climatic conditions. Indian Journal Agricultural Research, 49(3): 294-296.

Sarkar, R. K., Karmakar, S. and Chakraborty, A. 1997. Response of summer green gram (Phaseolus radiatus) to nitrogen, phosphorus application and bacterial inoculation. Indian Journal of Agronomy, 38: 578-581.

Sengupta, A., Gunri, S.K. and Basu, T.K. 2016. Performance of short duration groundnut (Arachis hypogaea L.) variety (TG 51) as influenced by nutrient management, Legume Research, 39(1): 91-95

Zalate, P. Y., and Padmani, D.R. 2010.Effect of organic manure and biofertilizer on growth and yield attributing character of kharif groundnut (Arachis hypogaea L.). International Journal of Agricultural Sciences, 5(2): 343-345.

\section{How to cite this article:}

Vala, F.G., P.M. Vaghasia, K.P. Zala and Buha, D.B. 2017. Effect of Integrated Nutrient Management on Productivity of Summer Groundnut (Arachis hypogaea L.). Int.J.Curr.Microbiol.App.Sci. 6(10): 1951-1957. doi: https://doi.org/10.20546/ijcmas.2017.610.235 